\title{
The Significance of the Method in Theology
}

In theology, the dispute on how to treat the reality of God has been long-standing and serious. Should the divine reality be considered in an exclusive and closed way, and thereby the relationship between man and God would be attributed merely secondary significance? Or should divine reality be regarded from a more open, religious point of view, where man is given an overriding role, and God comes second, perceived through human awareness of His actions? The latter option is currently on the rise, gaining more and more followers in Protestantism and Catholicism and the least in Orthodoxy. However, it is by no means entirely original or optimal. The main drawback of this approach is its focus on the human element, while the divine element is pushed into the shade. However, a credible view of reality of God regarding man and vice versa demands a balanced view of their mutual relations. This means, above all, a true recognition of the fact that their encounter is a process that is necessary, irreversible and unparalleled and combines the two into a single personal entity. Only on the basis of such a structure can the theological doctrine be developed in a reliable and comprehensive way.

It should be remembered, however, that the practice of theology is directly connected with the person, more precisely with one's faith and thinking, so that the acceptance of God and dialogue with Him are subjected to human rational and critical evaluation. This, in turn, helps to protect man from delusion or self-loss in his ultimate choice of God. ${ }^{2}$ Revelation, faith and kerygma remain unchangingly

${ }^{1}$ Rev. Jarosław Moskałyk, prof. dr hab. - research fellow in the Department of Systematic Theology, Faculty of Theology, AMU; e-mail:moskalyk@amu.edu.pl. ORCID: 0000-0001-91932433.

${ }^{2}$ Cf. C. Rychlicki, Uniwersytety $i$ Wydziaty Teologiczne we wspólnym kontekście kulturowym, “Teologia w Polsce" 2 (2008) 2, pp. 283-298. 
the subject of theology. Theology, by its very nature, has an individual dimension - it concerns the person and organizes his religious and social spheres; being official and universal, it spans all times, places and events. And although there is no simple equality or identity between faith and theology, they do not remain passive or relative to each other. Thus, it can be argued that there is no true theology without faith. But if there is such theology, it becomes a mere substitute for faith, whereas a properly developed theology always becomes a factor that animates and dynamizes human faith. Theological thinking, arranged in a system, is essentially grounded in models and methods that can assume different names, such as historical, speculative, narrative, linguistic, praxeological, etc. Based on this assumption, the reflection which will now follow is an attempt to show the significance of a real methodological form in the theological sciences.

\section{Methodological Theology}

Under the influence of modern secularization, a need emerged for the so-called bottom-up (popular) theology, intended to counterbalance classical theology, which after all, is firmly rooted in biblical studies, patristics, apologetics, dogmatics, etc. Popular theology, on the other hand, refers to a certain romantic idea, which assigns 'divine' attributes to the people. According to this concept, the role of theologians and theology is to promote the primacy of the people before God, but not necessarily combined into a single community of persons. For this community, the religious world assumes a fictional, mythical form without a true reference to objective reality. ${ }^{3}$ Theologians, on their part, should strive to present theological problems in a more modern dimension, that is, easily absorbed by the universal human community (E. Schillebeeckx). Seen from this perspective, theology does not have to seek the truth or expound it, because what matters above all is a feign message capable of seducing the masses.

Today, many theologians of the Western world think and perceive the development of theological doctrine in this way. An extremely negative consequence of such an attitude consists in the undermining or deliberate distortion of the essential truths of the Christian faith, namely, the existence of God, the Deity of Christ, the credibility of the Gospel, the reality of the sacraments, etc. But no less harmful is theological syncretism, which seeks to blur all doctrinal differences and combine different concepts into one in order to achieve supposedly greater credibility. A pretext for such a course of action can be found in the understanding of the spiritual and mystical dimension of the Church that stems

${ }^{3}$ Cf. C. Bartnik, Kryzys teologii wspótczesnej, "Collectanea Theologica" 61 (1991) 4, pp. 4-22. 
from the Orthodox ecclesiastical idea, which stands in contradiction to the visible and institutional dimension. The latter dimension would fulfil merely symbolic rather than actual roles in relation to the ecclesial community. This line of argument attempts to prove that theology does not have to be science in a strict sense, but only an auxiliary tool in examining religious reality. ${ }^{4}$ At most, it can change the human attitude to the temporal vicissitudes of individuals, communities, and the world. It is an irrationalism in the guise of a misguided emotional worship of unreason and absurdity. The language of transcendence ceases to be a creative theological inspiration and is replaced by colloquial and populist speech.

Today, an increasing disregard for philosophy and the element of abstraction in theological sciences has led to a huge methodological deficiency that trivializes the theological sense as such. ${ }^{5}$ Without the support of philosophical and abstract thinking, theology is endangered by mythologization and marginalization especially when considered in competition with the humanities. Currently, there is also a conspicuous trend to develop the so-called contextual theology, i.e. theology enriched by some original content, for example, political, economic, feminist and others. However, practicing theology with the intention of modernizing it, runs into the trap of over-emphasizing its secular and external aspects at the expense of a classical and holistic approach. This state of matters is tangibly reflected in the writings of the supporters of political or feminist theology (L. Boff, E. Drewermann, M. Werner and others), characterized by high interchangeability and confusion of concepts that results in relativism and arbitrariness of interpretation. At the same time, quite artificial and ridiculous problems are invented, such as the 'sexuality of God'.

Theology, however, should not be reduced to a simple narrative subordinated solely to Christian praxis. Theology by its very nature must have a doctrinal character, as its overarching purpose is to know and remain in the truth. ${ }^{6}$ And then to employ the truth in the service to man, to the community of persons, to people of faith, to the Church and to the Creator himself. By using the methodological key, we can explore the mystery of Christianity, the place and role of the person in the Christian structure and the importance of religious practice for the community of believers with greater clarity and in a more convincing way. The more attention is paid to the methodological aspect in theology, the less danger there is of it being subjectivized, synthesized, irrationalized, ideologized, etc.

${ }^{4}$ Cf. K. Mech, Logos wiary. Między boskościa a racjonalnościa, Kraków 2008, pp. 28-31.

${ }^{5}$ Cf. R.J. Woźniak, $O$ wspólnym losie metafizyki i teologii. Wprowadzenie do debaty u podstaw [in:] Metafizyka i teologia: debata u podstaw, red. R.J. Woźniak, Kraków 2008, pp. 5-12.

${ }^{6}$ Cf. J. Ratzinger, Prawda w teologii, tłum. M. Mijalska, Kraków 2005, pp. 23-25. 


\section{Method is Necessary in Theology}

The modern world is governed by science and technology, the essence of which is the method. It allows to develop different directions of scientific research and experimentation in a dynamic and expansive way. At the same time, they evolve in a planned, systematic, verifiable manner and can undergo critical assessment based on their cognitive content. ${ }^{7}$ The pressure of the methodology of non-theological sciences, in a sense enforces a new theological reflection on theology itself. But the fact is that theological experience, being extra-empirical, provides knowledge, which, unlike other sciences, does not encompass just some part of reality but its whole. At the basis of this experience lies a personal relationship between man and God, fulfilled so to say from within and imperceptibly. ${ }^{8}$ This relationship and its consequences are closely connected to truth because truth has an inner meaning. Inquiry into this relationship does not proceed in complete darkness and chaos, but acquires a higher status through a method defined by truth. This time the method derives from the truth that exists and is expressed in God. ${ }^{9}$

The method as a means and research tool enables us to capture with our senses the right relationship to transcendence. Some claim that in theology, especially dogmatic theology, there is only one method, namely the scholastic method. ${ }^{10}$ However, this is not the case at all, because there is a whole range of methods, such as historical, exegetic, hermeneutic, positive, narrative, comparative, critical and others, which even demand support from newer variants. All of them are undoubtedly used in theological doctrine, although it is also worth remembering that method in theological didactics is necessary as well. On this level, even greater flexibility seems to be required because of the nature of the theological subject matter, which cannot be reduced to pure abstraction or all the more so to illusion. Because what is at stake here there is an interpretation of the Living Christ, the history of salvation, almighty God, or the Creator's relationship with His creation. Theology in this case does not concern objects, things, some individual elements of our reality, but a personal world with regard to all creation and its future destiny. Therefore, selection of the right method in theology opens onto not only a correct interpretation of difficult cognitive issues, but also a more complete association of the human person with the Personal God.

Among the various methods of theology, one of the most desirable seems to be the historical method (K. Rahner, A. Darlap, O. Cullmann and others). Its premise

${ }^{7}$ C. Bartnik, Poznanie teologiczne, Lublin 1998, pp. 33-35.

${ }^{8}$ L. Scheffczyk, Die Theologie und die Wissenschaften, Aschaffenburg 1979, pp. 89-90.

9 John Paul II, Apostolic Constitution Ex corde Ecclesiae (15.08.1990), No. 1.

${ }^{10}$ Cf. C. Bartnik, Rozważanie o metodach w teologii dogmatycznej, "Roczniki Teologiczne" 42 (1995) 2, pp. 5-27. 
is to focus on the events that take place between God and man in order to compile, verify, explore, and evidence them. The process concerns individual and collective events, as well as simple and complex ones, which will then be translated into scientific theological language. The characteristic trait that distinguishes it from the older methods, such as classical Thomism, is its cognitive and futureoriented dynamism. Formerly, the focus was essentially on the past, and limited to creation, the history of Jesus, the origins of the Church, and other related facts, whereas now emphasis has shifted to issues that deal with the future and eschatology. This new theological approach, just as the previous ones, must be based on precision and objectivity. It cannot be confined to deduction or speculation, but should yield conclusions that provide some theological certainty. ${ }^{11}$ All the more so, as every method, salvation history method included, is underpinned by a search for truth through which the identification of supernatural reality with the whole person is accomplished.

Since theology in the temporal sense allows for an easier and more complete identification of the human person with the Person of Jesus Christ, the personalistic method, in addition to the salvation history method, plays an important role in reflection on the religious aspect of human history. Indeed, as personalism 'places' the person in the center of being, it sheds a whole new light on a person's relation towards the present and future world. ${ }^{12}$ Moreover, by applying the personalistic method and system, it becomes possible to place the truth about man and society at the very center of created reality. And at the same time, their perspective of development and fulfillment are shown in a dynamic relation to the present and future world.

\section{Diversified Methodological Pragmatism}

Humanism was a powerful influence on the development of the concept of historical truth, which in turn challenged the significance of rational faith. The Reformation went even further by separating a person's individual inner faith from their model of life and social attitude based on understanding, knowledge and religious sensuality. Today, there is a far-reaching controversy between historical and ahistorical thinking. This is partly due to the division into universal theology and local theology. The crux of the problem lies in overcoming the difference between historical truth that is indisputable because it is rooted in history, and subjective truth based on the so-called presumption, which is to some extent akin to illusion. And since truth with a limited degree of evidence is currently

${ }_{11}$ D. Tracy, Theologie als Gespräch. Eine postmoderne Hermeneutik, Mainz 1993, pp. 37-39.

${ }^{12}$ Cf. G. Barth, Personalizm w teologii, "Teologia w Polsce" 2 (2008) 2, pp. 357-366. 
gathering considerable momentum, the perception of real historical truth is becoming increasingly difficult. ${ }^{13}$ That is why historical thinking is sometimes confronted with allegations that it has a destructive impact on faith.

The resulting tension is to some extent a consequence of differing views on history which appeared as an offshoot of the development of theological doctrines, especially the Catholic and Orthodox ones. In general, it can be said that while Catholic theological thought has always sought a deeper connection with history, the Orthodox thought has done quite the opposite, as if escaping from historical considerations. If Orthodoxy attributes any significance to the historical development of its doctrine, it treats the historical aspect as ostensible and abstract, or ideal and mystical. Therefore, according to the Orthodox Christians, theology itself cannot be held hostage to any number of events, facts and circumstances, or, eventually, to ratio, reason and logic, as in Catholicism. Contradictions are admissible and interpreted in apophatic terms, but there is no acceptance of any arbitrariness in the treatment of the fundamental principles of faith and doctrine. ${ }^{14}$ Orthodox theology, therefore, stands in some opposition to Catholic theology, often claiming it to be excessively rationalized, speculative and rigorous, and most importantly, detached from the natural needs of believers as well as incapable of supporting the development of the ecclesial community (cf. N. Nissiotis, P. Evdokimov, W. Losski and others). Catholic theologians, on the other hand, accuse Orthodox theology of a high degree of hermeticism, internal inconsistency and lack of objectivity that stem from methodological relativism (cf. H. de Lubak, C. Bartnik).

The Protestant idea rejected the seriousness of the formerly recognized authority in favor of the Scripture, while denying the importance of history and tradition (M. Dibelius, K. Schmidt, R. Bultmann and others). Moreover, Protestant theological discourse became preoccupied with the biblical domain, excluding reason, sense and criticism. As a result, religious and spiritual values were deprived of any significant importance to the temporal world. And in an attempt to imitate the Orthodox, religious experience was reduced to the individual, private, and emotional spheres, in which case faith as a spiritual experience of one's relationship with Christ made only subjective sense. Over time, the role of faith and its influence began to be further deprecated by equating it solely with a practical religious attitude ${ }^{15}$ that also included a rule which impacted the state of personal morality and initiated religious acts. Thanks to the Scripture man obtains greater

13 M. Seckler, Zbawienie $w$ historii. Teologia historii w nauce świętego Tomasza z Akwinu, tłum. W. Szymona, Kraków 2015, pp. 15-16.

14 Cf. T. Kałużny, Oikonomia kościelna $w$ teorii i praktyce prawosławnej, Kraków 2018, pp. 67-72.

15 Cf. B. Mondin, The Principle of Analogy in Protestant and Catholic Theology, Dordrecht 1963, pp. 37-41. 
conviction in faith, but the Scripture itself is interpreted according to a cyclical principle (individual parts can only be understood in the light of the whole).

As a result of the divergent hermeneutic-methodological principles applied in Protestant and Orthodox theology, significant differences emerged between it and Catholicism in the interpretation of the role of the spiritual element of faith in relation to time and space. The fundamental difference is that Catholicism accepts the dynamism of the Word's influence in an extended perspective, i.e. embracing the entirety of life, including existence and practice. This pertains to the individual, the community of believers and all mankind, but also the creation, the world and the cosmos. Protestants and semi-Orthodox, on the other hand, narrow down the power of the Word only to an individual's personal life and some sphere of spiritual experience, but without penetrating into public, social, cultural life, etc., as in the Catholic stance. Ultimately, the greatest threat to theology in its entirety is any attempt to reduce methodological requirements as it negatively affects the cognitive aspect of theology and the order of religious thought. ${ }^{16}$ Modern intellectual trends in the humanities, under the influence of which theology necessarily remains, often try to move away from the ontic, rational and speculative premises in favor of simply analyzing or describing events in a relatively trivial form. For science in general, and all the more so for theology, this is a far unwelcome direction. Moreover, it promotes various absurdities, presenting them as seemingly relevant and even raising them to the status of credible claims.

\section{The Dialectics of Individual and Collective Facts}

According to the theological principle every public fact has to do with social structure, meaning that it reaches into the past and to some extent defines the future. On a purely human level, individual and collective facts continually come into contact and combine. Whereas secular and religious facts often overlap and precondition one another. The theologian's task is to constantly measure the contrast or contradiction between secular facts and religious facts. ${ }^{17}$ Some thinkers hold that all secular facts are at least indirectly connected with religious facts (P. Teilhard de Chardin, P. Ricoeur, G. Fessard and others). There are many who attribute a double structure to secular facts, regardless of their number and importance. ${ }^{18}$ What this actually means is that those facts acquire an external and

\footnotetext{
${ }^{16}$ Cf. J. Moskałyk, Dzisiejsza obecność teologa i teologii we wspólnocie akademickiej, "Poznańskie Studia Teologiczne" 35 (2019), pp. 82-83.

${ }_{17}$ Cf. J. Habermas, Wierzyć i wiedzieć, thum. M. Łukaszewicz, “Znak” 9 (2002), pp. 8-21.

${ }^{18}$ Cf. M. Napadło, Paul Tillich jako myśliciel (post)sekularny. Propozycja filozoficznej analizy religijnego wymiaru doświadczenia, "Studia Oecumenica" 18 (2018), pp. 381-396.
} 
internal dimension - a visible aspect and a hidden one (P. Tillich, J. Habermas, $\mathrm{Ch}$. Taylor and others). Finally, there are those for whom there is no relationship between secular and religious fact (S. Kierkegaard, K. Barth, R. Bultmann and others). Catholic theology, unlike its Protestant counterpart, tends to identify and consolidate religious facts, pointing to the power of their action (sacramental acts, cultic practice, the presence of Church offices). In theological reflection, however, priority is given to the relational aspect between various facts of a spiritual nature. This model of perception results in a more positive understanding of the facts of the temporal world. ${ }^{19}$

One of the basic methodological features in theology is the distinction and to some extent also confrontation of individual and collective historical facts with futuristic facts. They represent two different points of reference and two distinct interpretive phenomena. Christianity, and theology in particular, face the challenge of finding appropriate points of contact with extra-temporal facts, a trait that makes Christian inquiry unique and inimitable. By opening up to the future, theology does not have to be limited to the past, nor are facts 'closed' in the past. Historical facts are an important starting point for the structure of all time. Contrary to a common opinion, the theologian does not have access to the facts of both the past and the future, in a complete and infallible way. For him, religious facts, rooted in time but also directed towards timelessness, remain particularly inspiring. ${ }^{20}$ As an example of this complexity, it must be acknowledged that theological science, focusing on the religious faith of the original community of believers in Christ, considers and interprets it consistently in a future context. Ultimately, this shows that Christianity is not entirely dependent on purely historical facts, but is grounded in a whole that partakes both of the present and the future. ${ }^{21}$

The way to reach historical reality directly and deeply is through a person and in connection with a person, but also through the entire human community. Taken jointly, these two personal realities are largely the means of reproducing historical facts and their true realization in an individual and social sense. In the same way, it is a person that enables the linking of historical facts. Human cognitive abilities and dynamism of action cause the dialectical connection of objective history with a particular person and the community. In addition, historical facts are transformed into a higher level of theological interpretation and religious experience. If we take the history of creation as a starting point, we are able to see the salvific and non-salvific facts that it contains by viewing those events through

${ }^{19}$ Cf. C. Vagaggini, Teologia. Pluralizm teologiczny, thum. J. Partyka, Kraków 2005, pp. 43-44.

${ }^{20}$ Cf. J.R. Villar, „Praeparatio evangelica”, czyli o propedeutyce wiary we wspótczesnych czasach, "Teologia i człowiek" 3 (2013), pp. 77-89.

${ }^{21}$ Cf. G.L. Müller, Katholische Dogmatik. Für Studium und Praxis der Theologie, Freiburg 2007, pp. 48-49. 
the prism of the Divine economy of salvation. Historical facts also serve as either simple or higher signs, that call for a personal or collective self-interpretation and self-discovery in reality. For Christians, the most important historical and theological fact is Jesus Christ. As a historical figure, he remains for humanity both a secular and spiritual fact that needs to be translated in theology into soteriological language. ${ }^{22}$ This determines the use of an appropriate methodological key to process and give His history the right meaning.

Ultimately, the relationship between historical facts, including human inner life, is achieved through the dialectics of the action of objective events. In this historical stratum of facts, man always remains in his personal reference to the person of God and maintains true relationship with Him. The human person is a particular target of objective events that shape his subjectivity. ${ }^{23}$ On this basis, everyone can realize their own history of creation, which does not have to be determined by their relationship to others or even to God himself. However, man and humanity can better find themselves in reality by giving it their own meaning and destiny. All the same, salvific facts like the resurrection of Christ should not be reduced only to the experiential and historical sphere, but ought to be seen as a reflection of the supernatural power acting in history that receives its confirmation in the faith.

\section{The Language of Theology as a Language of Science}

In the present age of rapid development of the so-called technical speech based on ciphers and codes, doubts often arise concerning the comprehensibility of theological language. Technical speech uses a completely different form of communication and method of conveying content than theology. In this situation, theology loses its 'competitive' edge of linguistic accessibility mainly due to the specificity of its theoretical patterns and constructs. Another relevant issue pertains to the confusion of languages, and here too theological language is losing its power to convince people about the values of a higher dimension. Consequently, the position of theology in the modern world is currently so unfavorable that it faces the threat of alienation and annihilation. Most vulnerable of all is the language of systematic theology, and therefore also its auxiliary languages. As theological language is different from the common religious language, it is more difficult for it to correspond with the languages of experimental and practical sciences. ${ }^{24}$

${ }^{22}$ B. Welte, Czym jest wiara? Rozważania o filozofii religii, thum. W. Patyna, Warszawa 2000, p. 81.

${ }^{23}$ Cf. L. Giussani, Zmyst religijny, tłum. K. Borowczyk, Poznań 2000, pp. 222-224.

${ }^{24} \mathrm{Cf}$. A. Anderwald, Teolog a scientific community. Wzajemne odniesienia, przyczyny, in: Ja - Wspólnota. Perspektywa teologii fundamentalnej, red. E. Kotkowska, J. Moskałyk, Poznań 2009, pp. 131-149. 
Similarly, we can speak of the difference between theological language and the language of faith as based on different subjective premises. Nevertheless, some theologians oversimplify and, in the end, utterly obscure these differences. Their motivation stems from their fear of furnishing the language of faith with rational and scientific characteristics, as well as from the desire to marginalize it because of the prominence they wish to give to the personal and emotional experience of faith. Actually, however, these two languages are mutually dependent and complementary, as the language of faith is a living substance of the language of theology (A. Grabner-Haider). It is only together that they provide us with one religious language with two forms of external expression. Since these two forms of one 'religious' language are shaped in a direct relationship to God and transcendence, they remain as intrinsically conjoined as faith and knowledge. However, the religious or strictly theological language itself encompasses two strata: secular and 'sacred', both of which play an equally important role in interpreting the foundations of faith and supernatural reality.

The language of theology and the language of non-theological sciences refer to and cover different areas of knowledge and levels of cognition, although they can converge at a formal or even substantive level. Since they refer to the same material basis, there is often continuity and discontinuity between them (cf. G. Siewerth). Presumably, it is easiest to confidently build understanding and trust between theology and non-theological sciences on the grounds of the language of philosophy. ${ }^{25}$ Philosophy is a connection that allows, at least at a basic level, to bring the representatives of different sciences closer together. Ordinary language can also perform a positive function, which is clearly confirmed by the circle of Slavic cultures, where the effectiveness of its impact on theology and science in general is significant. In this case, ordinary language acts as a bridge between the language of faith and the language of science. ${ }^{26}$ However, excessive influence of ordinary language on science leaves a negative imprint and fundamentally weakens scientific discourse. Today, particular societies have much greater possibilities of shaping language than before, granting them far more control over, among other things, the cultural status of a language.

In the world of science, it is extremely important to maintain proper communication between the language of the sciences and the non-scientific language. This is often prevented today, on the one hand, by various inappropriate tendencies such as over-conceptualization and technicalization of language accompanied by a lack of openness to religion or mystery, and on the other hand by a propensity

${ }_{25}$ Cf. M. Gogacz, Filozofia czlowieka wobec teologii, "Studia Theologica Varsaviensia" 12 (1974) 1, pp. 177-191.

${ }^{26}$ Cf. P. Liszka, Język jako instrument i przedmiot teologii, pp. 346-347, http://156.17.54.194/ Content/836/Jezierska_25.pdf [accessed: 18.2.2021]. 
to acknowledge the superiority of mystery and worship over any notion, logic and deeper understanding of the meaning of religious life. Neither approach is satisfactory, so we need a balanced language that does not contrapose reason and faith, reason and values or authority and freedom. Moreover, it is necessary to follow the fundamental principle that theological language and the language of the sciences are not mutually exclusive, but require, especially nowadays, a revaluation and strengthening of the bonds that unite them. ${ }^{27}$ They must stand in relation not opposition to each other, in order to be able to raise both the human mind and the human spirit.

This means that neither the language of theology nor the language of science can be reduced to ordinary language or marginalized due to their individual translational specificity. These languages have an invaluable influence on the development of intellectual life, the universality of cognition, and taken jointly are an expression of the depth of the human spirit. ${ }^{28}$ Without them, the progress of research, exploration and experimentation, or the development of real knowledge, science and living culture would not be possible. And this in turn would limit the potential of man as an individual and of the human community as a whole, while at the same time impoverishing and limiting the world. Finally, the language of theology and the language of science are visible signs of a collective awareness that has evolved over the centuries and is gaining universal reach among all people. As a result, theologians and people of science have a high responsibility to ensure the clarity of their respective specialist language, but without attempting to isolate it from the natural language of communication, so that it does not become a language suspended in a vacuum or some kind of nonexistence. A well-developed scientific language, theological language included, has the natural feature of a capacity for dialogue with any language and does not want to be closed in some absolute system.

\section{Znaczenie metody w teologii}

\section{Streszczenie}

Refleksja na temat roli metody w teologii ma na celu ukazanie, że właśnie metoda pozostaje niezwykle ważnym narzędziem w odniesieniu do teologii jako nauki. Teologia podobnie jak inne dyscypliny naukowe jeśli ma odgrywać ważne posłannictwo w dziejach ludzkich, a zwłaszcza przy wyjaśnianiu pierwiastka religijnego i nadprzyrodzonego w świecie, to musi opierać się na

${ }^{27}$ Cf. C. Bartnik, Metodologia teologiczna, Lublin 1998, pp. 385-395.

${ }^{28}$ P. Liszka, Język..., p. 365. 
odpowiednim systemie metodologicznym. Bez niego traci na znaczeniu jako wartość poznawcza i inspirująca myśl ludzką. Obecnie jednym z najważniejszych zadań teologii jako nauki pozostaje zapewnienie niezbędnej równowagi między pogłębionym zmysłem wiary a praktyką religijną.

\section{Słowa kluczowe}

metoda, metodologia, język teologiczny, pragmatyzm teologiczny, wiara, kerygmat

\section{Keywords}

method, methodology, theological language, theological pragmatism, faith, kerygma

\section{Bibliography}

Anderwald A., Teolog a scientific community. Wzajemne odniesienia, przyczyny [in:] Ja - Wspólnota. Perspektywa teologii fundamentalnej, red. E. Kotkowska, J. Moskałyk, Poznań 2009, pp. 131-149.

Barth G., Personalizm w teologii, "Teologia w Polsce” 2 (2008) 2, pp. 357-366.

Bartnik C., Kryzys teologii współczesnej, "Collectanea Theologica" 61 (1991) 4, pp. 4-22.

Bartnik C., Metodologia teologiczna, Lublin 1998.

Bartnik C., Poznanie teologiczne, Lublin 1998.

Bartnik C., Rozważanie o metodach w teologii dogmatycznej, "Roczniki Teologiczne" 42 (1995) 2, pp. 5-27.

Giussani L., Zmyst religijny, tłum. K. Borowczyk, Poznań 2000.

Gogacz M., Filozofia człowieka wobec teologii, "Studia Theologica Varsaviensia" 12 (1974) 1, pp. 177-191.

Habermas J., Wierzyć i wiedzieć, tłum. M. Łukaszewicz, “Znak” (2002) 9, pp. 8-21.

John Paul II, Apostolic Constitution Ex corde Ecclesiae (15.08.1990), No. 1.

Kałużny T., Oikonomia kościelna w teorii i praktyce prawosławnej, Kraków 2018.

Liszka P., Język jako instrument i przedmiot teologii, http://156.17.54.194/Content/836/ Jezierska_25.pdf.

Mech K., Logos wiary. Między boskościa a racjonalnościa, Kraków 2008.

Mondin B., The Principle of Analogy in Protestant and Catholic Theology, Dordrecht 1963.

Moskałyk J., Dzisiejsza obecność teologa i teologii we wspólnocie akademickiej, "Poznańskie Studia Teologiczne" 35 (2019), pp. 79-90.

Müller G.L., Katholische Dogmatik. Für Studium und Praxis der Theologie, Freiburg 2007.

Napadło M., Paul Tillich jako myśliciel (post)sekularny. Propozycja filozoficznej analizy religijnego wymiaru doświadczenia, "Studia Oecumenica” 18 (2018), pp. 381-396.

Ratzinger J., Prawda w teologii, thum. M. Mijalska, Kraków 2005. 
Rychlicki C., Uniwersytety i Wydziały Teologiczne we wspólnym kontekście kulturowym, "Teologia w Polsce" 2 (2008) 2, pp. 283-298.

Scheffczyk L., Die Theologie und die Wissenschaften, Aschaffenburg 1979.

Seckler M., Zbawienie w historii. Teologia historii w nauce świętego Tomasza z Akwinu, tłum. W. Szymona, Kraków 2015.

Tracy D., Theologie als Gespräch. Eine postmoderne Hermeneutik, Mainz 1993.

Vagaggin C., Teologia. Pluralizm teologiczny, trans. J. Partyka, Kraków 2005.

Villar J.R. „Praeparatio evangelica”, czyli o propedeutyce wiary we współczesnych czasach, "Teologia i człowiek" 3 (2013), pp. 77-89.

Welte B., Czym jest wiara? Rozważania o filozofii religii, thum. W. Patyna, Warszawa 2000.

Woźniak R.J., O wspólnym losie metafizyki i teologii. Wprowadzenie do debaty u podstaw [in:] Metafizyka i teologia: debata u podstaw, red. R.J. Woźniak, Kraków 2008, pp. 5-12. 